\title{
Essayet som form ${ }^{\mathrm{I}}$
}

\author{
THeOdor W. Adorno
}

Bestemt til at se det belyste, ikke lyset selv. Goethe, Pandora

At essayet i Tyskland står i vanry som et blandingsprodukt; at det savner en overbevisende tradition; at man kun undtagelsesvis har kunnet indfri dets indtrængende fordring: alt dette er ofte nok blevet påpeget og påtalt. „Essayets form har endnu ikke gennemgået den selvstændiggørelse, som dens søster digtningen - for længst har lagt bag sig: at arbejde sig ud af en primitiv, udifferentieret samhørighed med videnskab, moral og kunst." 2 Men hverken ubehaget ved denne tilstand - eller den tankegang der reagerer imod den ved at gøre kunsten til et indhegnet reservat for irrationalitet, sætte erkendelse lig med organiseret videnskab, og derudover forvise alt, hvad der ikke underordner sig denne modstilling, som noget urent - har ændret noget ved denne landsdækkende fordom. Endnu i dag er det at blive hyldet som écrivain tilstrækkeligt til at blive holdt uden for enhver akademisk sammenhæng. Trods al den velprøvede indsigt som Simmel og den unge Lukács, Kassner og Benjamin betroede essayet, forstået som en overvejelse over specifikke, allerede kulturelt formede genstande, ${ }^{3}$ tolererer det filosofiske laugsvæsen stadig kun, hvad der er iklædt det almenes, blivendes og $\mathrm{i}$ dag så vidt muligt også oprindeliges værdighed, og skænker kun det konkrete åndsudtryk opmærksomhed i det omfang, det kan tjene som eksempel på de almene kategorier, eller i det mindste gøres gennemsigtigt på baggrund af disse. Den hårdnakkethed, hvormed dette skema holder sig $\mathrm{i}$ live, ville være lige så uforklarlig som de affekter, der investeres i det, hvis det ikke var fordi den næres af motiver som er endnu stærkere end den pinlige erindring om manglen på kultiverethed i en kultur, der historisk set knap nok aner hvad en homme de lettres er. I Tyskland vækker essayet modstand, fordi det minder om en åndelig frihed der fra sammenbruddet af den oplysning der allerede efter Leibniz var blevet lunken, og frem til i dag, på trods af rammer der sikrer en formel frihed - aldrig rigtigt kom til udfoldelse, men tværtimod altid var parat til at erklære det som sin egentlige bestemmelse at underordne sig denne eller hin instans. ${ }^{4}$ Essayet lader sig imidlertid ikke forvise til et særligt departement. Hvor videnskaben præsterer og kunsten skaber, afspejler essayet selv i sin anstrengelse endnu den barnlige fornøjelse der uden hæmninger begejstres over, hvad andre allerede har gjort før. Essayet tager det én gang elskede og hadede op igen, hvor andre, med en uindskrænket arbejdsmoral som forbillede, kun kan forestille sig ånden som skabelse ud af intet. Glæde og leg er væsentligt for essayet: det begynder ikke med Adam og Eva, men med det, det vil tale om. Det siger, hvad der falder det ind desangående, og bryder af, hvor det selv føler sig udtømt; ikke først dér, hvor der intet mere er tilbage. For så vidt falder det under det useriøses kategori. Dets begreber lader sig hverken konstruere ud fra en første grund eller fuldende i en sidste. Dets fortolkninger er ikke filologisk udpindet eller gennemtærsket, men er i princippet overfortolkninger, $-i$ hvert fald $i$ henhold til den form for årvågen forstand der som vægter over dumheden gør sig ufølsom for ånden. Subjektets anstrengelse for at trænge igennem, hvad der gemmer sig bag objektivitetens façade, stemples som tidsspilde - af lutter angst for 
negativitet i det hele taget. Så indviklet skal det slet ikke være. Den, der giver sig i kast med at tyde, i stedet for blot at tage for givet og henføre, påklistres det gule mærke der betyder: afmægtigt, med vildledte åndsevner, at væve og lægge betydninger ind, hvor der dog ingenting er at fortolke. At være kendsgerningernes mand, eller fritsvævende i luften: det er alternativet. Har man imidlertid først én gang ladet sig terrorisere af forbudet mod at mene mere end hvad der på givet tid og sted allerede var ment, er man dermed også prisgivet den falske intention, som mennesker og ting tillægger sig selv. At forstå betyder da blot at frilægge hvad den pågældende forfatter har villet sige, eller i bedste fald de individuelle psykologiske rørelser, som fænomenet er udtryk for. Men rent bortset fra, at det næppe lader sig afgøre hvad denne eller hin har tænkt og følt ved given lejlighed, ville der ikke være noget væsentligt vundet ved den slags indsigter. Forfatterens rørelser opløses i den objektive skikkelse, som opfanger dem. Til gengæld kræver den objektive betydningsfylde, som er forpuppet $\mathrm{i}$ ethvert åndsfænomen, netop den spontanitet $i$ form af subjektiv fantasi, der i den objektive disciplins navn bliver revset, for at komme til fuldt udtryk. Der kan ikke fortolkes noget ud, som ikke samtidig fortolkes ind. Kriterierne for dette er fortolkningens overensstemmelse med teksten og med sig selv, samt dens evne til at bringe genstandens forskellige dele i tale på én gang. På dette punkt nærmer essayet sig en æstetisk egenrådighed, der let kan beskyldes for blot at være et lån fra kunsten, som det imidlertid adskiller sig fra både ved sit begrebslige medium, og ved sin stræben mod sandhed blottet for enhver æstetisk illusion. Dette gik Lukács fejl af, da han i det brev til Leo Popper, som indleder Sjalen og formerne, kaldte essayet en kunstart.s Bedre står det imidlertid ikke til med den positivistiske tese, der hævder at intet som skrives om kunst, kan hævde at være kunstnerisk fremstilling, dvs. hævde en autonom form. Hele den positivistiske grundtendens, der betragter enhver mulig genstand for forskning som diametralt modsat subjektet, bliver her - som $\mathrm{i}$ alle andre henseender hængende $i$ en simpel modstilling af form og indhold: så sandt som man næppe overhovedet kan tale uæstetisk, blottet for enhver lighed med genstanden, om det æstetiske, uden at forfalde til filisteri og dermed allerede a priori afskære sig fra sagen. Indholdet, én gang for alle fastlagt efter protokolsætningens forbillede, skal efter positivistisk skik og brug være uafhængigt af måden, hvorpå det fremstilles, og denne til gengæld være rent konventionel, ikke begrundet i genstanden. Enhver rørelse i fremstillingens udtryk opfattes af den videnskabelige purisme instinktivt som en trussel mod dén objektivitet der ville springe frem i det øjeblik, subjektet trak sig tilbage, og dermed mod den sagen iboende grundfæstethed der kommer des mere til udtryk jo mindre den støtter sig på formen, - skønt denne dog netop har det som sit ideal at gengive sagen rent og ubesmykket. I sin overfølsomhed over for de angiveligt rent accidentelle former, kommer den scientistiske ånd i betænkelig nærhed af det stift dogmatiske. Det ansvarsløst henkastede ord bilder sig ind at begrunde sin ansvarlighed i sagen selv, og refleksionen over det åndelige bliver den åndløses privilegium.

Alle disse udslag af rancune er ikke bare usandhed. Afstår essayet ganske rigtigt fra på forhånd at aflede kulturelle dannelser af noget tilgrundliggende, mænger det sig til gengæld kun alt for ivrigt med den kulturelle trafik af prominens, succes og prestige knyttet til markedsprodukter. Romanbiografierne, og hvad der dermed følger af beslægtet programskriveri, er ikke bare en udartning, men en permanent tilbøjelighed for en form hvis skepsis over for den falske dybde ikke yder den nogen beskyttelse mod at slå om i forsiret overfladiskhed. Allerede hos Sainte-Beuve - der vel turde gælde som den nyere essayskrivnings udgangspunkt - er dette tydeligt, og med produkter som Herbert Eulenbergs silhouetter, det tyske forbillede for en syndflod af kulturel smudslitteratur, helt frem til filmene om ToulouseLautrec, Rembrandt og den Hellige Skrift, har det bidraget væsentligt til den neutralisering af åndelige frembringelser til blot og bart stykgods som i det hele taget, i nyere åndshistorie, har omklamret alt hvad der ovre østpå skammeligt kaldes ,arven“. Mest slående er forløbet måske hos Stefan Zweig, der i sin ungdom havde held med et og andet diffe- 
rentieret essay, for til sidst i sin Balzacbog at synke helt ned til en psykologi for det skabende menneske. Den slags skriveri kritiserer ikke de abstrakte grundbegreber, de begrebsløse data, de nedslidte klichéer, men forudsætter tværtimod alt dette stiltiende, men så meget mere indforstået. Brokker af forstående psykologi fusioneres med gængse kategorier fra dannelsesfilisterens verdensbillede, såsom „personlighed“ og ,irrationel“. Essays af denne type forveksler sig selv med den samme føljeton, som modstanderne af denne form forveksler den med. Løsgjort fra den akademiske disciplins ufrihed, bliver åndens frihed atter til ufrihed, underlagt kundekredsens samfundsmæssigt præformerede behov. Det uansvarlige - $i$ sig selv et træk ved enhver sandhed, der ikke slides op af ansvarlighed over for det bestående - føler nyt ansvar over for den etablerede bevidstheds behov: de dårlige essays er ikke mindre konforme end de dårlige afhandlinger. Virkelig ansvarlighed gælder imidlertid ikke blot autoriteterne og foreningerne, men også sagen selv.

At det dårlige essay fortaber sig $i$ personer, i stedet for at fremstille sagen, er formen imidlertid ikke uden skyld i. Adskillelsen af videnskab og kunst er irreversibel. Den kan kun overses af naiviteten hos den litteraturfabrikant der ser sig selv som et organisationsgeni, om ikke andet, mens han ophugger gode kunstværker til dårlige. Med genstandsgørelsen af verden, i og med den fremadskridende afmytologisering, er videnskab og kunst gået hver til sit: en bevidsthed, der ikke skelnede mellem anskuelse og begreb, mellem billede og tegn, ville - om den nogen sinde har fandtes - ikke kunne genoprettes med noget trylleslag, og ethvert forsøg på at genskabe den ville falde tilbage i det kaotiske. Kun som fuldbyrdelse af den formidlende proces kan en sådan bevidsthed tænkes: som utopi, således som den idealistiske filosofi fra Kant og frem forstod hvad de kaldte intellektuel anskuelse, en størrelse som ikke kunne have sit modstykke i nogen aktuel erkendelse. Hvor filosofien tror at kunne afskaffe den genstandsliggørende tænkemåde og dens historie - hvad man sædvanligvis kalder modsætningen mellem subjekt og objekt - ved at låne fra digtningen, eller ligefrem gør sig forhåbninger om at væren selv skulle kunne tale ud af en poesi sammenflikket af lige dele Parmenides og Jungnickel, løber den netop dermed lige $i$ armene på den trivialiserede kultursnak. Med en bondesnuhed rettet til som oprindelighed, afviser den at leve op til den begrebslige tænknings forpligtelse, skønt den dog selv skrev under på denne i samme øjeblik som den betjente sig af begreber til at danne sætninger og udsagn. Imens forbliver dens æstetiske moment en andenhånds, udvandet dannelsesreminiscens af Hölderlin, eller af ekspressionismen, eller allerhelst af jugendstilen eftersom ingen tanke kan overgive sig så grænseløst og blindt til sproget som idéen om den oprindelige udsigen foregøgler. Den vold som billede og begreb derved gensidigt øver mod hinanden, har sin rod i egentlighedens jargon, hvor der gives tremolerende udtryk for grebethed, uden at det dog siges, hvad det er man er så grebet af. Sprogets ambitiøse transcendering af meningen munder ud i en meningstomhed der er lige til at plukke af den selvsamme positivisme som man føler sig hævet over, og dog netop lægger op til med denne meningstomhed som positivismen kritiserer og som gøres op i dens spillemærker. Forhekset af sådanne tendenser kommer sproget - hvor det overhovedet endnu vover at røre på sig inden for videnskaberne - til at nærme sig kunsthåndværket, og den forsker der herefter vægrer sig mod sprog overhovedet, og hellere end at nedgøre ordet til at være blot en omskrivning af hans tal, foretrækker tabellen - der uforbeholdent indrømmer tingsliggørelsen af bevidstheden og for så vidt finder en slags form for den, uden at søge apologetisk tilflugt i kunsten - er den der, omend negativt, holder æstetikken højest i hævd. Ganske vist var kunsten, i dens hovedstrømning, altid så tæt forbundet med oplysningen, at den allerede fra antikken benyttede sig af videnskabelige opdagelser i sin egen teknik. Men kvantiteten slår om i kvalitet. Hvis teknikken i kunstværket absoluteres; hvis konstruktionen bliver total og udsletter sin modsætning, som samtidig er dens motiv, nemlig udtrykket; hvis altså kunsten foregiver at være umiddelbart videnskab, at være rigtig $i$ henhold til videnskabelige målestokke, da sanktionerer den blot et forkunstnerisk stofdyngeri, der i meningsløshed kun kan måle 
sig med de filosofiske seminarers Væren, og som går hånd $\mathrm{i}$ hånd med den tingsliggørelse som det dog indtil i dag har været det funktionsløses - kunstens - funktion at sætte sig op imod, det være sig i en nok så umælende og selv tingslig skikkelse.

Men selv om kunst og videnskab således skilles gennem historien, må deres modsætning dog på den anden side ikke hypostaseres. At afsky anakronistiske sammenblandinger er ikke det samme som at velsigne en kultur organiseret i departementer. Trods al deres uundgåelighed legitimerer disse departementer stadig afkaldet på den fulde sandhed. Idealet om det rene og ordentlige, som er fælles for bestræbelserne inden for en veritabel filosofi, indstillet på evighedsværdier, en nagel- og stikfast, vandtæt gennemorganiseret videnskab, og en begrebsløst anskuelig kunst, bærer vidnesbyrd om en repressiv orden. Man afkræver ånden et næringsbrev for at sikre, at den ikke overskrider de kulturelt fastlagte grænsedragninger, og dermed den officielle kultur som sådan. Man forudsætter i den sammenhæng, at al erkendelse potentielt lader sig omsætte i videnskab. De erkendelsesteorier, som skelner mellem den førvidenskabelige og den videnskabelige bevidsthed, har da også gennemgående opfattet dette som blot en gradsforskel. At det imidlertid aldrig er kommet videre end til forsikringen om denne omsættelighed, uden at levende bevidsthed nogen sinde i fuld alvor er blevet forvandlet til videnskabelig, siger noget om det prekære ved selve denne overgang, som en kvalitativ forskel. Selv den simpleste betragtning af bevidsthedslivet ville kunne vise $\mathrm{i}$ hvor ringe grad erkendelser, der dog på ingen måde er uforpligtende anelser, lader sig indfange af videnskabens net. Marcel Prousts værk, der lige så lidt som Bergson er fri for det videnskabeligt-positivistiske element, er ét stort forsøg på at udsige nødvendige og tvingende erkendelser om mennesker og sociale sammenhænge, der ikke uden videre kan indhentes af videnskaben, samtidig med at dets objektivitetsfordring af den grund hverken skal mindskes eller overlades til vag plausibilitet. Målestokken for en sådan objektivitet er ikke bekræftelsen af den opstillede tese gennem gentagen afprøvning, men derimod den enkelmenneskelige erfaring holdt sammen både $\mathrm{i}$ håb og desillusion. Gennem erindringen sætter den sine iagttagelser i relief, bekræftende eller modstridende. Den individuelt afsluttede enhed, som først lader helheden fremstå, ville imidlertid ikke kunne opdeles og ordnes på ny efter adskilte personer og apparaturer, svarende $\mathrm{fx}$ til psykologi og sociologi. Under presset fra den naturvidenskabelige ånd og dens overalt - også latent hos kunsmeren - tilstedeværende målsætninger, har Proust forsøgt - med en teknik som selv er dannet efter videnskabernes forbillede, en slags forsøgsopstilling - at redde eller genoprette, hvad der $\mathrm{i}$ den borgerlige idealismes dage, da den individuelle bevidsthed endnu havde tiltro il sig selv og ikke på forhånd krøb sammen i ly af organisatorisk censur, gjaldt som erkendelser for en mand af den uddøde art homme de lettres, som Proust en sidste gang opvækker som dilettantens ypperste form. Ingen ville det dog falde ind at afvise, hvad en erfaren har at sige, som ubetydeligt, tilfældigt og irrationelt, blot fordi det står for hans egen regning og ikke umiddelbart lader sig generalisere videnskabeligt. Omvendt vil dét $\mathrm{i}$ hans indsigter, som smutter gennem videnskabens netmasker, dermed også for bestandigt være tabt for den. Som åndsvidenskab ${ }^{6}$ svigter den sit eget løfte til ånden: at lukke op for dens frembringelser indefra. Den unge skribent, der går på universitetet for at lære, hvad et kunstværk er, hvad sproglig form, hvad æstetisk kvalitet, ja sågar æstetisk teknik er, vil som oftest kun få lidt spredt fægtning desangående med hjem, men under alle omstændigheder ting som er hentet fuldt færdige fra den til enhver tid gængse filosofi, for blot på mere eller mindre vilkårlig vis at blive overført på det pågældende værk. Vender han sig til gengæld mod den filosofiske æstetik, vil han dér møde sætninger på et abstraktionsniveau, der hverken står $\mathrm{i}$ forbindelse med de former, han prøver at forstå, eller virkelig er i berøring med det indhold, han famler efter. Alt dette er dog den i kunst og videnskab

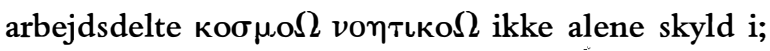
ejheller lader disse demarkationslinier sig ophæve alene ved god vilje og tværfaglighed. Men den ånd, der uigenkaldeligt har ladet sig modellere med naturbeherskelse og materiel produktion som forbil- 
lede, skyder erindringen om det overvundne stadium, hvor der stadig var håb for fremtiden, om en transcendens af de fastgroede produktionsforhold, fra sig, og dette lammer dens specialiserede behandling netop af dens specifikke genstande.

Over for den videnskabelige procedure og dens filosofiske fundering som metode, drager essayet ifølge selve sin idé - de fulde konsekvenser af systemkritikken. Selv de empiristiske teorier, der tillægger den uudtømmelige og ikke anticipérbare erfaring forrang frem for den faste, begrebslige orden, forbliver dog selv systematiske i det omfang de sætter betingelser for erfaringen, som tænkes at være mere eller mindre konstante, og udfolder denne i såvidt muligt ubeskadiget sammenhæng. Empirisme er - siden Bacon, selv en essayist - „metode“, lige så vel som rationalisme er det. Af alle tænkningens forskellige fremgangsmåder er det stort set kun essayet, der lader tvivlen på metodens ubetingede ret komme til udtryk. Essayet tager højde for bevidstheden om ikke-identitet, uden så meget som at nævne den; det er radikalt i sin ikke-radikalitet, i sin afståen fra enhver reduktion til et princip, i sin betoning af det partielle over for det totale, i sin stykagtighed. „Måske har den ædle herre de Montaigne følt noget lignende, da han gav sine skrifter den vidunderligt smukke og træffende betegnelse 'Essais'. For den simple beskedenhed i dette ord er samtidig et ophøjet storsind. Essayisten forstøder sine egne stolte forhåbninger, der ofte tror sig nær ved at have sagt det sidste ord: alt hvad han har at tilbyde, er jo bare diskussioner af andres digteriske frembringelser, til nøds af sine egne begreber. Men hans påtagelse af denne lidenhed - som dog rummer det dybest mulige tankearbejde over for tilværelsen - er ironisk, og det er med ironisk beskedenhed, han endnu engang understreger den." 7 Essayet adlyder ikke den spilleregel for organiseret videnskab og teori, som kræver - med Spinozas udtryk - at tingenes orden skal være den samme som idéernes. Fordi begrebernes restløse orden ikke er sammenfaldende med det virkelige, søger det ikke mod den lukkede, deduktive eller induktive opbygning. Det gør oprør ikke mindst mod den siden Platon indgroede doktrin, at det skiftende og forbigående skulle være under filosofiens værdighed, mod denne gamle uret mod det forgængelige, som gentager dommen over det $\mathrm{i}$ begrebets regi. Det viger tilbage for voldeligheden i det dogme, at abstraktionens slutprodukt, det tidsligt uforanderlige begreb, skulle være særligt ontologisk privilegeret. Den illusion, at ordo idearum skulle være lig med ordo rerum, bunder i forvekslingen af noget formidlet med det umiddelbare: lige så lidt som der kan tænkes noget faktisk uden begreb, fordi det at tænke også altid er at begribe, lige så lidt kan man tænke selv det reneste begreb uden noget som helst forhold til det faktiske. Selv hvad fantasien frembringer hinsides tid og rum, henviser dog altid til noget individuelt forekommende, hvorledes det så $\mathrm{i}$ øvrigt måtte være afledt heraf. Derfor lader essayet sig heller ikke kue af den depraverede dybsindighed, at sandhed og historie herefterdags må stå uforeneligt over for hinanden: givet at sandheden virkelig har en tidslig kerne, bliver historiens fulde udfoldelse til dens integrale moment; aposteriori bliver konkret til apriori, således som Fichte og hans efterfølgere krævede det $\mathrm{i}$ vendinger, der ganske vist forblev generelle. Henvisningen til erfaring - og denne får $\mathrm{i}$ essayet lige så meget substans som de rene kategorier gør i almindelig teori - er henvisning til historien i dens helhed: den rent individuelle erfaring, som bevidstheden tager udgangspunkt i som det mest nærliggende, er selv formidlet af den historiske menneskeheds overgribende erfaring. At denne altid skulle være middelbar, og kun enkelterfaringen umiddelbar, er blot et selvbedrag udsprunget af det individualistiske samfund og dets ideologi. Nedvurderingen af det historisk frembragte som teoretisk genstand, bliver således revideret af essayet: den adskillelse mellem en første teori og en heraf blot afledt kulturfilosofi, der forudsætter og bygger videre på den første - hvormed tabuet mod essayet rationaliseres teoretisk - står ikke til at redde. En åndelig fremgangsmåde, der ophøjer skellet mellem det tidslige og det tidløse til kanon, mister sin autoritet. Et højere abstraktionsniveau tilfører hverken tankerne større ærværdighed eller metafysisk indebyrd: det er snarere noget, der forflygtiges gennem abstraktionen, hvilket netop essayet gerne ville råde lidt bod på. Den gængse indvending imod essayet - 
at det er usammenhængende og tilfældigt - postulerer selv at totalitet er noget givet, dermed også identitet af subjekt og objekt, og foregiver således at helheden er noget man har fuldstændigt styr på. Essayets stræben er imidlertid ikke at opsøge og uddestillere det evige $\mathrm{i}$ det forgængelige, men snarere omvendt at eviggøre det forgængelige. Dets svaghed vidner om netop den ikke-identitet, som det har til opgave at udtrykke: den vidner om et overskud af intention frem for tingen selv, og dermed om den utopi som fornægtes $i$ inddelingen af verden $i$ det evige og det forgængelige. I det emfatiske essay lægger tanken den waditionelle idé om sandhed bag sig.

Dermed suspenderes tillige det traditionelle begreb om metode. Tanken har sin dybde afhængigt af hvor dybt den trænger ind i sagen, ikke af hvor dybt den fører den tilbage til noget andet. Essayet giver dette en polemisk drejning ved at behandle det som efter spillereglerne er noget afledt, men uden selv at føre denne afledning igennem til bunds. Det tænker sammen i frihed, hvad der selv finder sammen i den frit valgte genstand. Det flirter ikke ikke med noget hinsides formidlingerne - og her menes de historiske formidlinger, hvori hele samfundet er aflejret, men søger sandhedens udtryk som i sig selv historiske. Det spørger ikke efter nogen urbegivenhed - til ærgrelse for det samfundsmæssiggjorte samfund der, netop fordi det ikke tåler noget som det ikke selv har sat sit præg på, mindst af alt kan tåle at blive mindet om sin egen allestedsnærværenhed, og derfor er tvunget til bestandigt at medcitere den natur, som dets praksis ikke har levnet noget tilbage af, som ideologisk komplement. Essayet gør, ved sin blotte handling, op med den illusion, at tanken skulle kunne bryde ud af det som er $\vartheta \in \sigma \epsilon \iota$, kultur, over i det som er $\phi \theta \sigma \epsilon l$, af natur. Bundet som det er til det fikserede, til det indrømmet afledte, til det frembragte, holder det naturen $i$ ære ved at bekræfte, at den er hvad mennesket ikke længere er. Dets aleksandrinisme tager højde for at syrenen og nattergalen endnu, dér hvor det universelle net tillader dem en form for overlevelse, ved deres blotte eksistens kan give det indtryk, at livet endnu var i live. Det forlader hærvejen til oprindelserne - som blot fører til det allermest afledte, til væren, til den dobbelte ideologisering af det som nu engang er, uden i øvrigt at slippe helt af med den idé om umiddelbarhed uden hvilken ingen formidling har mening. For essayet er alle win af formidling lige umiddelbart givne for refleksionen.

Ligesom det giver afkald på urbegivenheder, således giver det også afkald på at definere sine begreber. Den gennemgribende kritik af definitionen er indvundet af filosofien ud fra de mest forskelligartede indfaldsvinkler: hos Kant, hos Hegel, hos Nietzsche. Videnskaben har imidlertid aldrig tilegnet sig denne kritik. Mens den af Kant indledte bevægelse, rettet mod skolastiske efterladenskaber i den moderne tanke, der i stedet for verbaldefinitioner henter sin begribelse af begreberne i den proces hvori de bliver til, bliver enkeltvidenskaberne, for at sikkerheden i deres operationer ikke skal forstyrres, stående ved den førkritiske forpligtelse til at definere: på dét punkt ligger neopositivisterne, for hvem videnskabelig metode er lig med filosofi, helt på linie med skolastikken. Essayet, på sin side, indoptager den antisystematiske impuls i selve sin fremgangsmåde, og indfører begreber lige så ugenert, lige så „umiddelbart", som det forefinder dem. Først gennem deres indbyrdes forhold præciseres de nærmere. I den forbindelse har det dog en forbundsfælle i begreberne selv: det er nemlig ren og skær overtro hos den produktorienterede videnskab, at begreber skulle være i sig selv ubestemte, og først modtage deres bestemmelse gennem deres definition. Forestillingen om begrebet som en tabula rasa er nødvendig for at videnskaben kan befæste sin fordring på eneherredømme: på at være den magt der alene sætter dagsordenen. I virkeligheden er alle begreber imidlertid allerede konkretiseret af det sprog, hvori de optræder. Netop i sådanne betydninger tager essayet udgangspunkt, og fører dem videre, $i$ kraft af sin egen væsenstilkytning til sproget. Essayet søger at hjælpe dem $\mathrm{i}$ deres forhold til begreberne: at optage i refleksionen, hvad der allerede bevidstløst er benæunt i sproget. Dette er også, hvad der foresvæver betydningsanalysen i fænomenologien, der imidlertid gør begrebernes henførelse til sproget til fetich. Over for dette stiller essayet sig lige så skeptisk som over for definitioner: det påtager sig 
uden omsvøb den indvending, at man aldrig kan være helt sikker på, hvad man skal forstå ved begreberne. Det gennemskuer nemlig, at kravet om strikte definitioner længe har tjent som påskud for, gennem fastlåsende manipulationer af begrebernes betydninger, at skille sig af med det irriterende og farlige ved tingene som lever i dem. Alligevel er essayet hverken noget der vil klare sig uden almene begreber - selv det sprog som ikke feticherer begreberne, kan ikke undvære dem - eller noget der omgås vilkårligt med dem. Det tager derfor fremstillingen mere alvorligt end de fremgangsmåder, der adskiller metode og genstand, og som er ligeglade med, hvorledes deres genstandsgjorte indhold fremstilles. Spørgsmålet til udtryksmåden skal genvinde i præcision hvad der gik tabt ved at give afkald på afgrænsningen, uden at dog på noget tidspunkt det der siges skal svigtes til fordel for én gang foreskrevne begrebsbetydninger. På det punkt var Benjamin den ubestridte mester. En sådan præcision kan imidlertid ikke forblive atomistisk: ikke i ringere, men tværtimod i mere udpræget grad end den definitoriske fremgangsmåde kræver essayet en vekselvirkning mellem sine begreber, $i$ en åndelig erfaringsproces. I denne erfaring indgår begreberne ikke $i$ et kontinuum af operationer, tanken skrider ikke hele tiden frem i samme reming, men de forskellige momenter fletter sig sammen som i et tæppe. Egentlig tænker den tænkende slet ikke, men gør sig selv til skueplads for åndelig erfaring, uden at løse den op. Skønt erfaringen er kilde også til den traditionelle tænknings impulser, eliminerer denne gennem sin form erindringen om den. Essayet vælger den derimod netop til forbillede, uden dog som reflekteret form ligefrem at efterligne den. Det formidler den gennem sin egen begrebslige organisering; dets fremgangsmåde er, om man vil, metodisk umetodisk.

Måden hvorpå essayet tilegner sig begreberne, kunne bedst af alt sammenlignes med hvorledes et menneske forholder sig, der $\mathrm{i}$ et fremmed land er tvunget til at kaste sig $\mathrm{ud} \mathrm{i}$ at tale landets sprog, $\mathrm{i}$ stedet for på skolemestervis at stykke det sammen af elementer. En sådan læser da uden ordbog. Når han tredive gange har set det samme ord, hver gang $i$ en ny sammenhæng, vil han være mere sikker på dets betydning end hvis han havde slået de forskellige betydninger op én for en i ordbogen, hvor de som oftest er for snævert bestemt $\mathrm{i}$ forhold til de skiftende sammenhænge, og samtidig for vagt $\mathrm{i}$ forhold til de umiskendelige nuancer som sættes af hver given kontekst. Ligesom en sådan læremåde ganske vist risikerer at begå fejl, således også essayet som form: for sin nærhed til en åben åndelig erfaring må det betale med den mangel på sikkerhed, som den etablerede tankenorm frygter som døden. Det handler dog ikke så meget om, at essayet ikke lever op til en vished blottet for tvivl, som at det gør op med selve dette ideal. Det finder sin sandhed i sin bevægelse ud over sig selv, ikke i skattegraverens tvangsmæssige søgen efter fundamenter. Dets begreber forklares af lyset fra en terminus ad quem, som er skjult for det selv: ikke af en åbenlys terminus ab quo; og netop heri udtrykker essayets metode selv den utopiske intention. Samtlige dets begreber må fremstilles således, at de bærer hinanden indbyrdes, at hver enkelt artikulerer sig gennem sine respektive konfigurationer med de øvrige. Diskret adskilte elementer finder her selv sammen i en læselig sammenhæng; essayet rejser hverken stillads eller bygning. Konfigurationen udkrystalliserer sig imidlertid først gennem elementernes bevægelse: den er et kraftfelt, - så sandt som enhver åndelig frembringelse under essayets blik må forvandle sig til et kraftfelt.

Essayet udfordrer nænsomt idealet om clara et distincta perceptio, om vished uden tvivl. I det hele taget lod essayet sig fortolke som én stor indvending mod de fire regler som Descartes' Discours de la méthode opstiller ved indgangen til den nyere vestlige videnskab og dens teori. Den anden af disse regler - at opdele genstanden $\mathrm{i}$,så mange dele ... som overhovedet muligt, og som fornødent for at opløse dem bedst muligt" 8 - indfører den form for elementaranalyse, i hvis tegn den traditionelle teori sætter de begrebslige ordningsskemaer lig med værens struktur. Essayets genstande modsætter sig imidlertid, som artefakter, elementaranalysen, og lader sig kun konstruere ud fra deres specifikke idé: det er ikke uden grund, at Kant behandlede kunstværker og 
organismer som analoge, omend han dog lige så ubestikkeligt forsvarede deres forskellighed mod enhver romantisk obskurantisme. Helheden må lige så lidt hypostaseres som begyndelsesgrund, som de elementer der er analysens produkt. I forhold til begge orienterer essayet sig efter den idé om vekselvirkning der strengt taget lige så lidt lader sig forlige med en søgen efter elementer som med en søgen efter det elementare. Momenterne lader sig hverken udlede rent af helheden, eller omvendt. Helheden er monade, og er det dog alligevel ikke: dens momenter viser, da de er af begrebslig art, ud over den specifikke genstand, hvori de mødes; men essayet forfølger dem ikke til et punkt, hvor de kunne legitimeres ud over denne: det ville blot føre den ud i en slet uendelighed. Essayet rykker tværtimod så tæt på genstandens hic et nunc, at den udskiller sig $\mathrm{i}$ de momenter hvori den har sit liv, i stedet for blot at være genstand.

Den tredie cartesianske regel, ,at lade mine tanker følge en orden, ved at begynde med de simpleste og lettest erkendelige, for derefter ligesom gradvis at stige op til erkendelsen af de mere sammensatte," står i grel modsætning til essayformen, for så vidt dette tager udgangspunkt i det komplekse, ikke i det simpleste, kun allerede alt for velkendte. Med rette forholder essayet sig som den der begynder at læse filosofi og allerede har en vis idé derom for øje: han vil næppe begynde med de simpleste forfattere, hvis common sense som oftest sludrer hen over det, der netop var værd at opholde sig ved, men snarere række ud efter det, der anses for svært, og som formår at kaste lys bagud over det simple som en tilbagelagt form af ,tankens stilling til objektiviteten“. Naiviteten hos den student, for hvem kun det vanskelige og formidable lige netop går an, er klogere end det voksne pedanteri der med løftet pegefinger formaner tanken om, at den først må forstå det enkle, før den kan vove sig ud i det komplekse, som dog er det eneste der drager den. En sådan udsættelse af erkendelsen opnår kun at forhindre den. Ved sin afstandtagen til forståelighedens convenu, til forestillingen om sandhed som en virkningssammenhæng, pålægger essayet fra første færd at tænke sagen lige så flerfoldig, som den er, og optræder dermed som korrektiv til den forstokkede primitivitet, der gerne optræder sammen med den gængse ratio. Mens videnskaben, sin sædvane tro, bringer det vanskelige og komplekse ved en antagonistisk og monadologisk opsplittet virkelighed ind under forsimplende modeller som forfalsker den, for derpå atter at differentiere den ud ved hjælp af foregivet materiale, ryster essayet hele denne illusion om en simpel, dybest set i sig selv logisk verden, som er så god til at forsvare det der nu engang er, af sig. Essayets differentiering er ikke en senere tilføjelse, men selve dets medium. Den etablerede tankegang betragter gerne essayet som noget, der alene hører erkendelsens psykologi til, og mener dermed at have frakendt det enhver forpligtende gyldighed; den højstemt videnskabelige besværgelse af det lidt for kløgtige, fremkaldes dog $\mathrm{i}$ virkeligheden slet ikke af den næsvist uforpligtende metode, men derimod af det foruroligende ved genstanden, som den lader komme til syne.

Den fjerde cartesianske regel - „overalt at opstille så fuldstændige opregninger og så almene oversigter“ at man „kunne være sikker på ikke at udelade noget" - dukker uforandret op igen i Kants polemik mod Aristoteles' „rapsodiske“ tænkning. Den svarer til den anklage mod essayet, at det, som det hedder i skolemestersproget, ikke er udtømmende, - skønt enhver genstand, og da især en åndelig, rummer uendeligt mange aspekter som alene den erkendendes intention kan beslutte at inddrage eller udelade. Den „almene oversigt“ ville kun være mulig hvis det på forhånd stod fast at den genstand, der skal behandles, går op $\mathrm{i}$ behandlingens begreber, og der dermed ikke blev noget til overs, som disse ikke kunne anticipere. Reglen om fuldstændigheden af alle enkeltled foregiver imidlertid, $i$ forlængelse af den forste antagelse, at genstanden lader sig fremstille $\mathrm{i}$ en ubrudt deduktionssammenhæng, hvilket er en rent identitetfilosofisk forudantagelse. Som det gjaldt kravet om definition, har også den cartesianske regel, som tankepraktisk anvisning, overlevet det rationalistiske teorem, som den hvilede på: omfattende oversigt og kontinuitet $\mathrm{i}$ fremstillingen kræves nu også af de empiriske videnskaber. Dermed forvandles imidlertid hvad der hos Descartes skulle 
våge over erkendelsens nødvendighed som en intellektuel samvittighed, til noget vilkårligt: en ,frame of reference", en aksiomatik, der for at tilfredsstille det metodiske behov og sikre helhedens plausibilitet skal anbringes ved begyndelsen, uden længere selv at kunne godtgøre sin gyldighed eller evidens; eller det står - i den tyske version - som et „udkast“, hvis pathos om at sigte mod væren selv blot dækker over dens subjektive forudsætninger. Kravet om kontinuitet i tankegangen forudskikker tendentielt også samstemmigheden i genstanden, dens egen harmoni. En kontinuert fremstilling ville stå i modsætning til en antagonistisk genstand, med mindre den bestemte kontinuiteten også som diskontinuitet. I essayet som form melder sig ubevidst og teorifjernt behovet for også i den konkrete fremgangsmåde at annullere de $\mathrm{i}$ teorien allerede overvundne fordringer på fuldstændighed og kontinuitet. Hvis essayet æstetisk tager afstand fra den trangbrystede metode der jo nu engang ikke vil udelade noget, følger det dermed tillige et erkendelseskritisk motiv. Den romantiske opfattelse af fragmentet som en uafsluttet frembringelse, der gennem selvrefleksion fortsætter i det uendelige, forfægtede dette anti-idealistiske motiv midt $i$ idealismen. Også $i$ sin sprogføring må essayet aldrig give indtryk af at have forklaret sagen således, at der ikke skulle være mere at sige om den. Selvrelativering er immanent i dets form: det må gå frem, som om det når som helst kunne bryde af. Essayet tænker i brud, så sandt som virkeligheden er hjemsøgt af brud, og finder sin enhed gennem bruddene, - ikke ved at glatte dem ud. Enstemmighed i den logiske orden lyver om det væsentligt antagonistiske ved det som denne orden blev påklistret. Diskontinuitet er et væsenstræk ved essayet; dets genstand er altid et øjebliksbillede af en konflikt. Alt imens det afstemmer begreberne indbyrdes, ved hjælp af det kræfternes parallellogram som sættes af genstandene, viger det uden om det overbegreb, hvorunder de samlet skulle kunne underordnes: hvad dette blot foregøgler at yde, erkender essayets metode som umuligt - og forsøger alligevel at yde det. Selve ordet 'forsøg', hvori tankens utopi om at ramme plet parres med bevidstheden om egen fejlbarlighed og foreløbighed, giver - som de fleste historisk blivende terminologier - et vink om formen, der vejer så meget tungere som det ikke er udsagt programmatisk, men melder sig af sig selv som karakteristik af en intention der føler sig frem. Essayet må lade totaliteten komme til syne ved et udvalgt eller forefaldende partielt træk, uden dog at hævde totaliteten som faktisk nået. Det korrigerer det tilfældige og enkeltstående ved sine indsigter ved at mangfoldiggøre, bekræfte eller begrænse sig, det være sig gennem sin egen bevægelse, eller i det mosaikagtige forhold til andre essays, - ikke ved at abstrahere over de særkendetræk som er vundet $i$ disse indsigter. „Således er der altså forskel på et essay og en afhandling. Den essayistiske skrivemåde tilkommer den der skriver eksperimenterende, som altså drejer sit emne frem og tilbage, spørger, beføler, prøver og gennemreflekterer det, går løs på det fra forskellige sider, og for sit indre blik samler hvad han ser, og sætter ord på det, som genstanden har ladet komme til syne under de gennem skrivningen skabte betingelser."9 Ubehaget ved denne procedure - følelsen af at dette kunne blive ved og ved efter forgodtbefindende - rummer såvel sin sandhed som sin usandhed. Sin sandhed, for så vidt essayet faktisk ikke slutter, og tilmed udstiller denne uformåen som parodi på dets eget apriori, - hvorpå det lægges til last, hvad man egentlig skulle bebrejde de former som udvisker sporene af vilkårlighed. Usandt er på den anden side dette ubehag, for så vidt essayets konstellation trods alt ikke er vilkårlig i den forstand, som det må forekomme en filosofisk subjektivisme der henfører sagens tvang til den begrebslige orden. Essayet determineres af sin genstands enhed, herunder enheden i den teori og erfaring som er aflejret $i$ genstanden. Dets åbenhed er ikke en vag overgivelse til følelse og stemning, men finder sine konturer gennem sit indhold. Essayet vægrer sig mod idéen om hovedværket, der på sin side atter afspejler idéerne om skabelse og totalitet. Dets form stemmer overens med dén kritiske tanke, at mennesket ikke er nogen skaber, at intet menneskeligt er skabelse. Det fører sig hverken selv - henvist som det altid er til noget i forvejen skabt - frem som skaberværk, eller stræber efter noget altomfattende, hvis totalitet kunne sammenlignes med ska- 
belsens. Essayets totalitet - den enhed der tilkommer en indadtil gennemkonstrueret form - er det ikke-totales totalitet, der heller ikke som form hævder den tese om identiteten af tanke og genstand, som den i sit indhold forkaster. Frigørelsen fra identitetstvangen forlener undertiden essayet med det som altid undslipper den officielle tænkning: momentet af uudslukkelighed, af farve der ikke kan bleges. Visse fremmedord hos Simmel - cachet, attitude - vidner om denne intention, uden dog at blive behandlet teoretisk som sådan.

Essayet er på én gang mere åbent og mere lukket end den traditionelle tænkning bryder sig om. Det er mere åbent, for så vidt det i selve sit afsæt negerer systematikken, og lever desto bedre op til sig selv, jo strengere det formår at fastholde dette: systematiske rester i essays, som f.eks. i infiltreringen af litterære studier med færdigtillavede, almindeligt antagne filosofemer, der skulle gøre dem mere acceptable, er ikke en tøddel bedre end psykologiske trivialiteter. Mere lukket er essayet til gengæld, for så vidt det arbejder emfatisk med sin fremstillingsform. Bevidstheden om ikke-identitet mellem fremstilling og genstand pånøder fremstillingsformen en uindskrænket anstrengelse. Kun heri består det kunstlignende ved essayet; $i$ andre henseender er det nødvendigvis - $\mathrm{i}$ kraft af de begreber, som optræder i det, og som jo ikke blot medbringer deres betydning, men også deres teoretiske henvisningssammenhæng - beslægtet med teorien. Ganske vist forholder det sig lige så forsigtigt til denne som til begrebet: det lader sig hverken tvingende udlede af teorien - kapitalbrøleren i alle Lukács' senere essayistiske arbejder - eller gør regning på kommende synteser. En grum skæbne truer den åndelige erfaring, jo mere krampagtigt den forhærdes til teori og fører sig frem som om den havde de vises sten i hånden. Og dog stræber også åndelig erfaring, ifølge hele sin mening, mod en sådan objektivering. Denne antinomi afspejles i essayet. Ligesom det indoptager erfaringer og begreber udefra, således indoptager det også teorier. Blot forholder det sig ikke til dem ved at indtage et standpunkt. Hvor essayets standpunktsløshed er mere end blot naiv, hvor den er på højde med genstandens forrang, og netop be- nytter sin nærhed til genstandene som middel mod begyndelsens forbandelse, da virkeliggør det så at sige parodisk den polemik fra tankens side mod den blotte standpunktsfilosofi, som ellers forbliver afmægtig. Essayet æder de teorier op som står det nærmest; det stræber altid mod den faste menings likvidering - også den, hvori det selv tog afsæt. Det er, og var fra første færd, den kritiske form par excellence, og mere præcist - som immanent kritik af åndelige frembringelser, som konfrontation af disse med deres begreb - ideologikritik. „Essayet er formen for åndens kritiske kategori. Den der kritiserer, må nemlig nødvendigvis eksperimentere, må skabe betingelser, hvorunder genstanden bliver synlig i nyt lys, endnu engang anderledes end hos en given forfatter, og frem for alt må genstandens udlevethed $n u$ tages op til afprøvning og undersøgelse; og netop dette er jo pointen med den subtile variation, som kritikeren underkaster sin genstand." fordi det ikke anerkender noget andet standpunkt uden for sit eget, anklages for standpunktsløshed og relativisme, så spøger her netop den forestilling om sandheden som noget „færdigt“, et hierarki af begreber, som Hegel - ingen ynder af standpunkter lagde i grus. Heri mødes essayet med sin diametrale modsætning: den absolutte videns filosofi. Begge vil redde tanken ud af dens vilkårlighed ved reflekterende at inddrage den $i$ sin egen fremgangsmåde, $i$ stedet for at maskere den som umiddelbarhed.

Nævnte filosofi forblev ganske vist behæftet med den inkonsekvens, at den på én gang kritiserede det abstrakte overbegreb, det blotte „resultat“, $i$ en indadtil diskontinuert proces' navn, og dog samtidig, på idealistisk vis, talte om dialektisk metode. Derfor er essayet mere dialektisk end dialektikken selv, dér hvor denne blot foredrager sig selv. Essayet tager den hegelske dialektik på ordet: sandheden i totaliteten må hverken spilles umiddelbart ud mod de enkelte udsagn, eller endeliggøres til et enkeltudsagn; derimod tages det singulæres sandhedsfordring bogstaveligt helt frem til det punkt, hvor det bliver til evidens for dets usandhed. Det vovede, foregribende, ikke helt indløste ved enhver essayistisk detalje drager andre til sig som dens negation: den usandhed, som essayet helt bevidst geråder ud i, er 
det element, hvor det finder sin sandhed. Noget usandt ligger ubestrideligt også i dets blotte form, hvor det forholder sig til noget kulturelt forudformet, afledt, som om det var noget i sig selv værende. Jo mere energisk essayet suspenderer begrebet om en første grund og vægrer sig mod at spinde kultur ud af natur, jo dybere når imidlertid dets erkendelse af kulturens eget naturgroede væsen. Helt frem til i dag er det den blinde natursammenhæng $\mu \theta \vartheta \circ \Omega$ - som foreviger sig i kulturen, og dette er netop hvad essayet reflekterer: forholdet mellem natur og kultur er dets egentlige tema. Ikke uden grund fordyber det sig - i stedet for at ,føre dem tilbage“ - i kulturfænomener som anden natur, som anden umiddelbarhed, for ved sin stædighed at ophæve illusionen om noget sådant. Lige så lidt som oprindelsesfilosofien tager det fejl af væsensforskellen mellem kultur og det underliggende; men for essayet er kultur ikke et epifænomen, der dækker over væren og må destrueres, men også det underliggende er $\vartheta \in \sigma \epsilon l$, nemlig det falske samfund. Derfor sætter det ikke oprindelsen højere end overbygningen. Dets frihed i valget af genstande, dets suverænitet over for alle priorities, det være sig faktum eller teori, skylder det den omstændighed, at alle dets genstande så at sige er lige nær ved centrum: ved det princip som forhekser dem alle. Essayet glorificerer ikke beskæftigelsen med det oprindelige som noget mere oprindeligt end beskæftigelsen med det formidlede; fordi oprindelighed for essayet selv er genstand for refleksion, og dermed noget negativt. Dette modsvarer en situation, hvor oprindelighed, som et åndens standpunkt midt i en samfundsmæssiggjort verden, forlængst er blevet en løgn: en løgn der strækker sig fra ophøjelsen af historisk givne begreber fra historisk givne sprog til urord, til akademisk undervisning i ,creative writing", og til den professionelt iværksatte primitivitet blokfløjter og finger painting - hvorved den pædagogiske elendighed stiller sig an som metafysisk fortjenstfuldhed. Heller ikke tanken undslipper Baudelaires digteriske oprør mod naturen som samfundsmæssigt reservat: heller ikke tankens paradiser kan være andet end kunstige, og netop dér strejfer essayet om. Fordi der, med Hegels ord, ikke findes noget mellem himmel og jord som ikke er formidlet, bevarer tanken kun sin troskab mod det umiddelbare ved at bevæge sig gennem det formidlede, mens den omvendt bliver dettes bytte i samme øjeblik, den griber uformidlet ud efter det uformidlede. Listigt slår essayet sig ned i teksterne, som om de var noget slet og ret givet, og oppebar autoritet; på denne vis vinder det, uden at forfalde til den første grunds bedrag, en - det være sig aldrig så tvivlsom - grund under fødderne, omtrent som tidligere tiders teologiske eksegese af skrifter. Tendensen er imidlertid den modsatte, den kritiske: at konfrontere teksterne med deres eget emfatiske begreb, med den sandhed som hver enkelt af dem vil sige, også selv om den ikke vil sige den, for dermed at ryste dens hævdelse af sig selv som kultur, og tvinge den til at betænke sin egen usandhed: netop det ideologiske skin, hvorved kulturen afslører sig som naturforfalden. Under essayets blik bliver den anden natur bevidst om sig selv som en første.

Når essayets sandhed således bevæger sig gennem dets usandhed, betyder det, at den ikke skal søges i den blotte modsætning til det uredelige og udskældte ved det, men netop i dets mobilitet, dets mangel på dette faste, som videnskaben overførte fra ejendomsforholdene og gjorde til et krav til ånden. De, som tror at forsvare ånden mod det usolide, er dens fjender: ånden selv er, én gang frigjort, mobil. Så snart den vil mere end blot administrativt at gentage og tilrettelægge det til enhver tid værende, er der noget udækket ved den: en sandhed, som ikke længere havde et islæt af spil, ville ikke være andet end tautologi. Historisk er essayet da også beslægtet med retorikken, som det videnskabelige sindelag lige siden Descartes og Bacon har villet sætte på porten, indtil den som en logisk konsekvens i den videnskabelige tidsalder sank ned til at være blot en videnskab sui generis, den om kommunikation. Det er sandt, at retorikken altid vedrørte tanken $\mathrm{i}$ dens tilpasning til det kommunikative sprog. Den sigtede mod det umiddelbare: mod tilhørerens behovstilfredsstillelse. Essayet fastholder nu netop - gennem den fremstillingens autonomi, hvorved den adskiller sig fra den videnskabelige meddelelse - spor af det kommunikative, som denne 
taber på gulvet. Den tilfredsstillelse som retorikken vil berede tilhøreren, sublimeres $i$ essayet til idéen om lykken ved et frit forhold til genstanden, som tilkender denne mere af sit eget end hvis den blot blev skånselsløst underordnet idéernes orden. Den scientistiske bevidsthed, som har front imod enhver antropomorfistisk forestilling, har altid været knyttet til realitetsprincippet, og er lykkefjendtligt som dette. Skønt lykke skal gælde for målet med al naturbeherskelse, fremstiller den altid samtidig lykken som regression til blot og bar natur. Det kommer til udtryk selv i de højeste filosofier, selv hos Kant og Hegel. Fornuften, på hvis absoluttc idé de hænger al deres pathos, bliver samtidig af dem selv stemplet som næsvis og respektløs, så snart den giver sig til at relativere det gældende. Over for denne tilbøjelighed fastholder essayet et moment af sofistik. Lykkefjendtligheden i den officielle kritiske filosofi er især mærkbar i Kants transcendentale dialektik, som ønskede for evigt at sikre grænsen mellem forstand og spekulation og - med en sigende metafor - at forhindre „udsvævelse i intelligible verdener“. Idet den fornuft, der kritiserer sig selv, hos Kant skal stå med begge ben solidt på jorden, skal begrunde sig selv, afskærmer den sig, i sit inderste princip, mod alt nyt, og mod den nysgerrighed - tankens lystprincip - som også eksistentialontologien lægger for had. Hvad Kant indholdsmæssigt erkender som fornuftens formål - nemlig menneskehedens fremståen, utopien - fornægtes af formen, af den erkendelsesteori, som ikke tillader fornuften at gå ud over det erfaringsområde, der i det mekaniske samspil mellem simpelt materiale på den ene side, og uforanderlig kategori på den anden, skrumper ind til blot at være det der nu engang altid har været. Essayets genstand er imidlertid det nye som nyt, som noget der ikke lader sig oversætte tilbage til det gamle, i dets bestående former. Idet essayet reflekterer sin genstand så at sige uden vold, bliver det samtidig til en stum klage over at sandheden forrådte lykken, og dermed også sig selv; og denne klage er det som nedkalder vreden over essayet. Det overtalende $i$ retorikken fjerner sig $i$ essayet - analogt til den måde, hvorpå mange træk skifter funktion i den autonome musik - fra sit oprindelige for- mål, og bliver til en ren bestemmelse ved fremstillingen som sådan, til det tvingende ved den konstruktion som ikke søger at afbilde sagen, men at genskabe den af dens begrebslige disiecta membra. De anstødelige overgange $\mathrm{i}$ retorikken, hvori association, verbale tvetydigheder og forsømmelse af logisk syntese skulle gøre det lettere for tilhøreren og udlevere den svagere part til talerens vilje, forenes imidlertid i essayet med dettes sandhedsindebyrd. Essayets overgange lader hånt om den bindende slutning, til fordel for krydsforbindelser mellem elementer som den diskursive logik ikke levner noget rum for. Det benytter tvetydigheder, ikke af sjuskeri, og ikke i uvidenhed om det scientistiske forbud mod sådanne, men for at få fat i hvad den blotte tvetydighedskritik, adskillelsen af de forskellige betydninger, kun sjældent når frem til: at overalt, hvor det samme ord dækker forskellige ting, er disse aldrig helt forskellige, men at ordets enhed peger på en det være sig aldrig så skjult enhed i tingen, - hvilket ganske vist ikke, som det sker $\mathrm{i}$ vor tids restaurative sprogfilosofier, må forveksles med sprogslægtskaber. Også herved strejfer essayet den musikalske logik, den stringente og dog begrebsløse overgangs kunst, for at bibringe det talende sprog noget som det mistede under den diskursive logiks herredømme, omend denne på den anden side ikke lader sig slet og ret overspringe, men kun overliste, $\mathrm{i}$ kraft af det indtrængende subjektive udtryk. Essayet står nemlig ikke i noget simpelt modsætningsforhold til den diskursive fremgangsmåde. Det er ikke ulogisk; det adlyder selv logiske kriterier for så vidt som dets sætninger må føje sig til en samstemmende helhed. Ingen rene modsigelser må blive stående, med mindre de er begrundet af rene modsigelser i sagen. Essayet udvikler blot sine tanker anderledes end ifølge den diskursive logik. Det udleder hverken af et princip, eller drager slutninger af kohærente enkeltiagttagelser. Det koordinerer elementerne, i stedet for at subordinere dem; og det er først indbegrebet af dets indhold - ikke dets fremstillingsmåde - som kan sammenholdes med de logiske kriterier. Er essayet vel, sammenlignet med de former, hvori et færdigt forefundet indhold indifferent meddeles, mere dynamisk end den traditionelle tænkning, i kraft af 
spændingen mellem fremstillingen og det fremstillede, er det dog samtidig, som konstrueret sideordning, mere statisk. Deri består alene dets slægtskab med billedet, dog således at essayets statik består af spændingsforhold der så at sige er stillet $i$ bero. Den blide eftergivenhed $\mathrm{i}$ essayistens tankegang pånøder ham en større intensitet end den diskursive tænknings, fordi essayet ikke som denne blot skrider blindt, automatisk fremad, men i hvert eneste øjeblik må reflektere over sig selv. Denne refleksion omfatter imidlertid ikke blot dets forhold til den etablerede tænkning, men også dets forhold til retorik og kommunikation. I modsat fald vil det, som forfængeligt tror sig hævet over videnskaben, blot befinde sig på et niveau langt under den.

Essayets aktualitet er anakronismens aktualitet. Tiden er det mere ugunstigt stemt end nogen sinde. Det søndermales mellem på den ene side en organiseret videnskab, hvor alle slås om at kontrollere alt og alle, og hvor alt, hvad der ikke er skåret til efter den givne konsensus, udgrænses med den skinhellige respekt for det intuitive eller spændende, på den anden side en filosofi, der tager sig til takke med den tomme og abstrakte rest som videnskaben endnu ikke har sat sig på, og netop derfor gøres til genstand for en geskæftighed $\mathrm{i}$ anden potens. Essayet bekymrer sig imidlertid om den blinde side af sine genstande. Det vil med begreber sprænge en åbning for det som ikke indgår $i$ begreberne, eller som gennem de modsætninger, begreberne indvikles $i$, røber at deres netværks formodede objektivitet blot er en subjektiv foranstaltning. Det vil polarisere det opake og frigøre de deri bundne kræfter. Det tilstræber konstruktionen af det i rum og tid givne indhold, og konstruerer begrebernes sammengroethed på samme måde som de må tænkes at være groet sammen i genstanden selv. Det unddrager sig det diktat som forordner prædikaterne at besidde hvad der siden Symposion tilskrives idéerne som ,evigt værende, hverken tilblivende eller forgående, hverken foranderlige eller aftagende:“ „en i sig selv og for sig selv evig, uforanderlig væren,“ og forbliver dog ikke desto mindre idé, idet det ikke kapitulerer, ikke bøjer sig for det, som blot nu engang er. Dets målestok er imidlertid ikke det evige, men snarere et entusiastisk fragment fra Nietzsches sene værk: „Antag, at vi sagde ja til blot et enkelt øjeblik, så har vi dermed sagt ja ikke blot til os selv, men til alt, hvad der er. For intet står for sig selv, hverken i os eller i tingene: og når blot én enkelt gang en streng af vor sjæl har sitret og tonet af lykke, så var alle evigheder nødvendige betingelser for at dette kunne ske - og hele evigheden var i dette ene øjeblik, hvor vi sagde ja, frikendt, udfriet, retfærdiggjort og bekræftet. " "I Blot med den tilføjelse, at essayet mistror også en sådan lykke og retfærdiggørelse. For den lykke, der for Nietzsche var hellig, kender den intet andet navn end det negative. Selv de højeste manifestationer af ånden, som bringer den til udtryk, er også altid medskyldige $\mathrm{i}$ dens forhindring, sålænge nemlig de forbliver intet mere end ånd. Derfor er essayets inderste formprincip kætteriet. Ved genstanden selv synliggøres, i modstand mod tankens ortodoksi, hvad det stiltiende var dennes objektive formål at lade forblive usynligt.

På dansk ved Kasper Nefer Olsen Trykt med tilladelse fra Suhrkap Verlag 


\section{Noter}

I. Her oversat efter Noten zur Literatur I, pp 9-33. Tilegnet Jutta Burger. At oversætte Adorno er ikke uproblematisk. De mange stilistiske ejendommeligheder kan undertiden gøre meningen svært fattelig; og for den, der har fattet den, kan det omvendt være svært at forstå, hvad disse manierismer egentlig skulle gøre godt for. En række mindre retoriske overgreb (utallige tilfælde af hysteron proteron, ellipser, latinismer, osv) på det tyske sprog, som pedantisk reproduceret på dansk ville tangere forbrydelser mod læseligheden, er derfor diskret ignoreret. Nærværende oversættelse har endvidere ræsonneret, at siden dens modtager er en læser, hvis modvilje mod unødig møje med den tyske ordbog vi må forudsætte, var der ingen grund til i stedet at udlevere ham til den latinske: ord som „desultorisch,“ „urgieren" og „Konzeption“ oversættes derfor ubekymret ved tilsvarende danske ord (uden at der $\mathrm{i}$ øvrigt heri ligger nogen form for sproglig oprindelseshigen). Adornos egen appel til en læser uden ordbog skulle dermed $\mathrm{i}$ det mindste ikke være lagt hindringer $\mathrm{i}$ vejen: også oversættelsen er et 'forsøg', og må prøve sig frem til sin egen tone. Herunder følger forresten en oversættelse af mindre gængse fremmedsproglige (dog ikke engelske) udtryk, der står som sådanne i Adornos tekst, i den orden hvori de optræder:

écrivain (fr) forfatter, i emfatisk forstand

homme des lettres (fr) menneske der forstår at læse og skrive, i emfatisk forstand

a priori (lat) forud for erkendelsen givet

rancune (fr) nag

$\kappa о \sigma \mu о \Omega \nu о \eta \tau \iota \kappa o \Omega$ (gr) intelligibel verden

ordo idearum/ordo rerum (lat) idéernes/tingenes orden

a posteriori (lat) først med erkendelsen givet

$\vartheta \epsilon \sigma \epsilon \iota / \phi \theta \sigma \epsilon \iota$ (gr) det af mennesket satte / det af naturen udsprungne

tabula rasa (lat) ubeskrevet (egl: udvisket) tavle

terminus ad quem (lat) slutpunkt, konklusion

terminus ab quo (lat) udgangspunkt, præmis

clara et distincta perceptio (lat) klar og distinkt perception

hic et nunc (lat) her og nu

convenu (fr) vedtægt

ratio (lat) fornuft

$\mu \theta \vartheta \circ \Omega$ (gr) myte, hos Adorno = den blinde, irrationelle tvangs diskurs

sui generis(lat) $\mathrm{i}$ sin egen art (ret)

disiecta membra (lat)spredte lemmer (Horats)

2. Georg von Lukács, Die Seele und die Formen, Berlin I9II, p. 29.

3. Jvfr. Lukács, op. cit, p. 23: „Essayet taler altid om noget allerede formet, eller $i$ bedste fald om noget der allerede har været; det er altså et væsenstræk ved det, at det ikke drager nye ting frem af det tomme intet, men blot ordner sådanne ting som på en eller anden måde allerede har levet, på en ny måde. Og fordi det blot ordner dem på en ny måde, i stedet for at forme noget helt nyt af det formløse, er det også forpligtet på dem, og må altid udtale 'sandheden' om dem, finde udtryk for deres væen." “ 4. Dette var, som bekendt, netop hvad der skete for den omtalte unge Lukács, da han som lidt mindre ung nåede frem til, at den ,instans," tanken måtte ,underordne sig," var - det Kommunistiske Partis Centralkomité. Dermed var det, som Adorno også senere lader skinne igennem, nat med Lukács som essayist.

Det kritiske spørgsmål, som må rettes til Adornos egen tekst, er naturligvis om noget lignende sker her, mellem linierne: om den stædige genkomst på den ene side af scientismekritikken, på den anden side af den retorisk en anelse skingre Heidegger-polemik, betyder at essayet her til syvende og sidst vurderes under andre mailestokke end sine egne, sagen iboende? Spørgsmålet er ikke rent akademisk: hvis nemlig det gøres til essayets højere mening at finde en kurs mellem positivismens Skylla og fænomenologiens Kharybdis, har det dermed fảet en rent $y d r e$ (epokal) bestemmelse og telos, og man kunne da tænke sig den misforståelse, at en skribent ville ønske at skrive et 'essay' alene fordi essayet efter Benjamin, Lukács og Adorno gælder for at være den "gode“ form, ikke fordi en genstand kræver det. Det ville, som man ser, være essayets dialektiske undergang: en genrejsning af det formens apriori som det er hele Adornos ærinde med essayet om essayet at gøre op med. (O. a).

5. Jvfr. Lukács, op cit, p. 5 et passim.

6. 'Geisteswissenschaften' kaldes i Tyskland som bekendt hvad vi endnu kalder 'humanvidenskaber'. (O. a).

7. Lukács, op. cit, p 2 I.

8. Adorno citerer her den tyske oversættelse af Descartes' Philosophische Werke, Leipzig 1922 (Bd I, p I5), og vi oversætter denne oversættelse. Imidlertid forstyrres meningen en anelse af, at Adorno ændrer sætningens grammatiske objekt. Descartes skriver: ,de diviser chacune des difficultés que j'examinerais en autant des parcelles qu'il se pourrait, et qu'il serait requis pour les mieux résoudre, “ hvilket vil sige: ,at opdele ethvert af de problemer, som jeg skulle undersøge, $i$ så mange bestanddele som muligt, og som fornødent for at løse dem bedst muligt" (Discours de la méthode, Paris I987 [1637], p 42). Descartes taler altså ikke - som det kunne se ud i Adornos text - om at opløse (auflösen) genstandens dele, men blot om at løse problemerne. (O. a). 9. Max Bense, Über den Essay und seine Prosa, in: Merkur I (1947), p 4I8.

Io. Bense, op. cit, p 420.

II. Nietzsche, Werke Bd I0, Leipzig I906, p 206 („Der Wille zur Macht" II, \1032). 